\title{
Effects of changing freestall area on lameness, lying time, and leg injuries on dairy farms in Alberta, Canada
}

\author{
Emily Morabito, ${ }^{11}$ Herman W. Barkema, ${ }^{*}$ Edmond A. Pajor, ${ }^{*}$ Laura Solano, ${ }^{*}$ Doris Pellerin, $\dagger$ and Karin Orsel ${ }^{*}$ \\ ${ }^{*}$ Department of Production Animal Health, Faculty of Veterinary Medicine, University of Calgary, 3330 Hospital Drive NW, Calgary, \\ AB T2N 4N1 Canada \\ †Department of Animal Science, Laval University, 2325 Rue de l'Université, Ville de Québec, QC G1V 0A6 Canada
}

\section{ABSTRACT}

Cow comfort is of increasing importance in the dairy industry, due to an increased focus on animal welfare. However, whether producer changes to the cows' environment affect cow comfort has not been well characterized. Our objectives were to: (1) quantify the effect of freestall area changes on the prevalence of lameness, leg injuries, and average lying time; and (2) compare cow comfort outcomes on farms that had never had an assessment of cow comfort to farms that had had a previous assessment of cow comfort. A sample of 60 Holstein-Friesian cows were selected on each of 15 farms that made changes to the freestall area after an assessment of cow comfort (change, CHG); 15 farms that did not make changes to the freestall area after an assessment of cow comfort (no change, NC); and 14 farms that had yet to be evaluated (new farms, NF). Cows in NC and NF were lame 1.50 and 1.71 times more often, respectively, than cows on CHG farms. Additionally, daily lying time was 0.33 and $0.62 \mathrm{~h} / \mathrm{d}$ lower in $\mathrm{NC}$ and $\mathrm{NF}$, respectively, than on CHG farms. The prevalence of hock and knee injuries was not different among the 3 groups of farms. No differences were detected in the parameters of interest when comparing NF with NC farms; therefore, we concluded that the $\mathrm{NC}$ group was not biased by a previous assessment of cow comfort. Farms in the CHG group had a lower prevalence of lame cows and greater lying time than the $\mathrm{NC}$ and NF groups.

Key words: dairy cattle, animal welfare, lameness, leg injury, hock injury

Received December 15, 2016.

Accepted April 7, 2017.

${ }^{1}$ Corresponding author: emily.morabito@ucalgary.ca

\section{INTRODUCTION}

Worldwide, cow comfort and animal welfare are important topics for the dairy industry (Barkema et al., 2015). Quantifying animal-based measures (e.g., prevalence of lameness and injuries, lying time, and production information), evaluating environmental factors (e.g., barn design and stall dimensions), and determining management practices (e.g., record keeping and management training) are proven methods of assessing animal welfare (National Farm Animal Care Council, 2009; Vasseur et al., 2013; Solano et al., 2015). Furthermore, prevalence and risk factors for animalbased measures of cow comfort-including prevalence of lameness (Solano et al., 2015), prevalence of injuries (Zaffino Heyerhoff et al., 2014), and lying behavior (Solano et al., 2016) - on freestall dairy farms have been well characterized, providing baseline information.

Lameness reduces cow comfort and welfare, because it causes pain (Rushen et al., 2007), negatively affects lying time (Solano et al., 2016), and is associated with low BCS (Zaffino Heyerhoff et al., 2014). Lameness prevalence varies by region, housing system, and management practice (Cook and Nordlund, 2009), ranging from 0 to $55 \%$ in North America (Cook et al., 2004; von Keyserlingk et al., 2012; Solano et al., 2015). Hock and knee injuries are important animal welfare concerns, because they can cause pain and discomfort (Huxley and Whay, 2006). In a recent Canadian study, 47 and $24 \%$ of cows had hock and knee injuries, respectively (Zaffino Heyerhoff et al., 2014). Lying time is considered a good indicator of cow comfort, because it is optimal for cows to lie down 12 to $13 \mathrm{~h} / \mathrm{d}$ (Weary et al., 2009), and suboptimal stall design reduces lying time (Solano et al., 2016). Lying time can also be linked with animal welfare: cows with restricted lying time have a higher risk of aggressive behavior, decreased productivity, poor hoof health, and compromised overall health (Ito, 2009; Nechanitzky et al., 2016; Wang et al., 2016).

The Dairy Farmers of Canada and the National Farm Animal Care Council created the Canadian Dairy Code of Practice, containing recommended practices and 
requirements for Canadian dairy producers (Vasseur et al., 2013). To supplement this code, a cow comfort assessment was developed to help producers assess their compliance with the Canadian Dairy Code of Practice (Vasseur et al., 2013). These assessments were implemented in several Canada-wide studies (Zaffino Heyerhoff et al., 2014; Solano et al., 2015), allowing participating producers to determine how their farms compared with regulations in the Canadian Dairy Code of Practice.

Although information about cow comfort and welfare is available for Canadian dairy producers (e.g., the Canadian Dairy Code of Practice and conferences), it is not known whether they use this information to make changes that would improve cow comfort and welfare on their farm. Additionally, effects on measures of cow comfort after implementation of changes have not yet been reported. The objectives of this study were to: (1) quantify the effect of freestall area changes on lameness, leg injuries, and average lying time; and (2) compare cow comfort outcomes on farms that had never had an assessment of cow comfort to outcomes on farms that had had a previous assessment of cow comfort.

\section{MATERIALS AND METHODS}

The method of assessing cow comfort has been described in Solano et al. (2015) and Solano et al. (2016). Methods included evaluations of animal-based measures, environmental measures, and management factors (Zaffino Heyerhoff et al., 2014). Standard operating procedures used were consistent with previous studies and are reported on the Canadian Dairy Research Portal (http://www.dairyresearch.ca/animal-comfort-tool. php).

\section{Farm Selection and Farm Visits}

The 91 freestall dairy farms in Alberta, Canada, that participated in a previous evaluation of comfort and lameness (Solano et al., 2015) were invited to participate in the present study, with a target of 15 farms per study group. Thirty of these previously assessed farms were selected for participation because they met all the criteria. Remaining farms were not included because of logistic and scheduling conflicts. As well, 45 Alberta freestall dairy farms that did not participate in the Solano et al. (2015) study were also invited to participate as a contemporary control group. Fifteen of those 45 farms were selected for the present study (Figure 1), because some of the farms that met the inclusion criteria did not fit into the farm visit schedule. Inclusion criteria are presented in Table 1 and were consistent with the previous study, as described by Solano et al. (2015).

A total of 44 freestall dairy farms in Alberta were visited between April and December of 2015. Participating farms included 15 that made changes to their freestall area (change, CHG); 15 that did not make changes, or made changes that were not related to the freestall area (no change, NC); and 14 that were not enrolled in the Solano et al. (2015) study and had had no previous cow comfort assessment (new farms, NF). Initially, the NF group consisted of 15 farms, but 1 was excluded from the analyses because of a disruption in data collection (Figure 1). Each farm was visited twice, with an interval of 5 to $7 \mathrm{~d}$ between visits. During the first visit, both environmental and animal-based measures were collected. During the second visit, a face-toface questionnaire was conducted, along with any data collection (animal-based and environmental) that had not been completed during the first visit. Data were collected by trained research personnel from the University of Calgary ( $\mathrm{AB}$, Canada), including 1 graduate student (EM) and 2 research assistants. All protocols and questionnaires were approved by the University of Calgary Animal Care Committee (AC14-0216) and Research Ethics Board (REB14-2120).

\section{Cow-Based Measures}

Forty cows between 10 and 120 DIM were selected on each farm, because this period is known to be a critical one for lameness (Green et al., 2002). If the farm did not have 40 lactating cows between 10 and 120 DIM, cows >120 DIM were added, reflective of the parity distribution on farm. As well, another 20 cows between 121 and 310 DIM were selected to ensure that all stages of lactation were represented. Pen was not considered in the selection process, but pens were excluded if they did not contain freestalls. This occurred on 2 farms, and cows from these pens were excluded from the study. Additional cows from alternative pens with freestalls were selected according to the selection criteria.

Selected cows were assessed for lameness, knee injuries, hock injuries, lying time, claw length, leg cleanliness, and BCS using standard operating procedures as described on the Canadian Dairy Research Portal (https://www.dairyresearch.ca/animal-comfort-tool.

php). In short, cows were video-recorded for lameness as they exited the milking parlor. Recordings were subsequently viewed and cows were scored for lameness based on the presence of a head bob, asymmetrical steps, and a limp. Cows were considered lame if they had a limp (Solano et al., 2015; Vasseur et al., 2015). Knee and hock injuries, claw length, leg cleanliness, 
and BCS were assessed in the milking parlor or in the freestall area (if data could not reliably be collected in the milking parlor). Hock injuries were scored on a scale of 0 to 3, separately for the left and right joints (Gibbons et al., 2012). Lying time was measured using electronic data loggers (HOBO Pendant G Accelera-

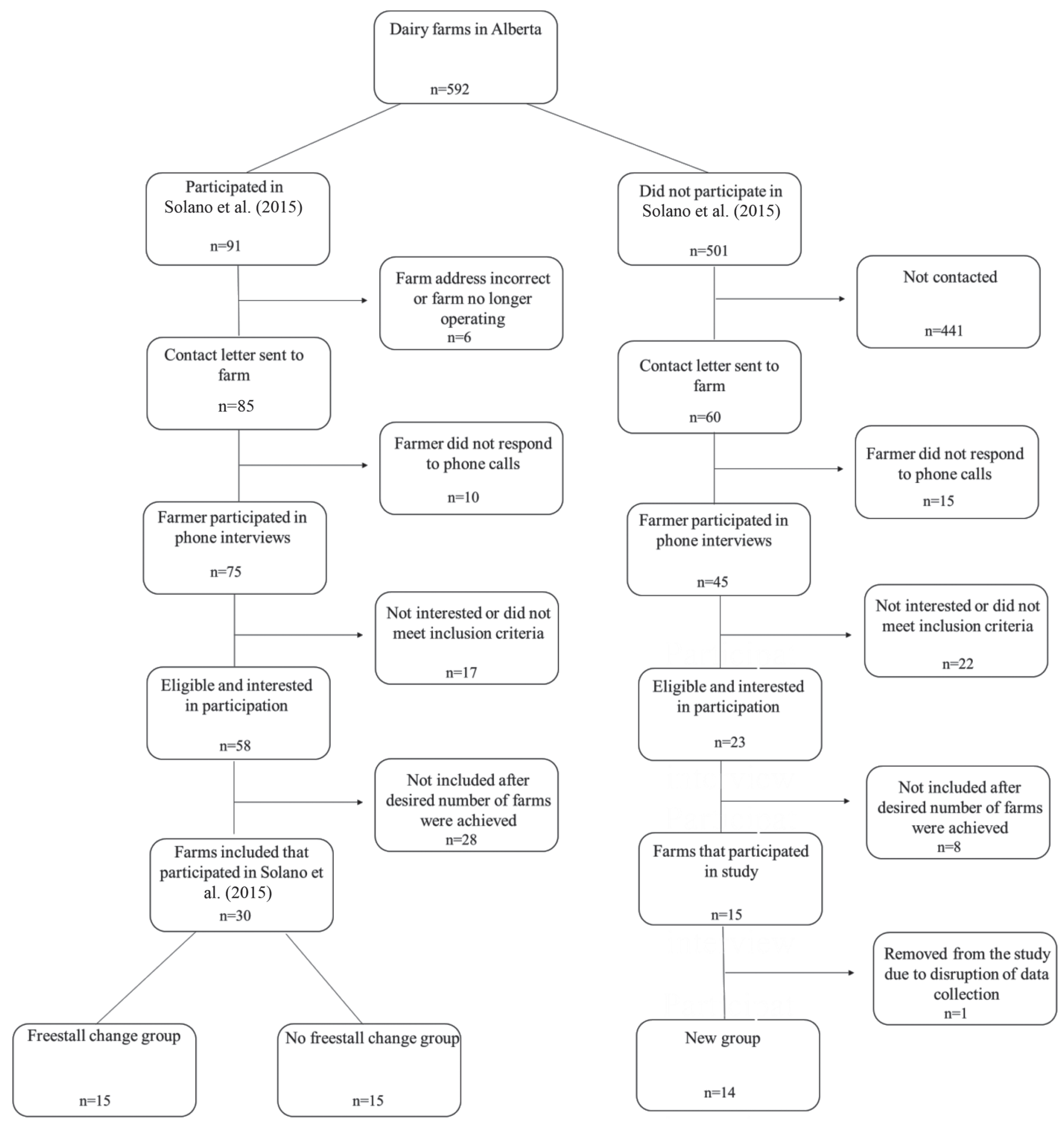

Figure 1. Selection process for participating farms in their respective study groups. 
tion Data Loggers; Onset Computer Corp., Pocasset, MA). The loggers were placed on the cows' hind leg to measure lying time for 4 full days. Claw length was estimated by assessing the angle at which each of the hind claws contacted the ground. Claws were scored as overgrown if the angle of their hoof was $<45^{\circ}$, or not overgrown if the angle of the hoof was $\geq 45^{\circ}$ (Solano et al., 2015). For leg cleanliness, the lower hind right leg was scored on a scale of 0 (clean) to 3 (caked manure on $>50 \%$ of the lower leg), a method adapted from Cook (2006). The BCS was scored in 0.25 increments (Vasseur et al., 2013). Data including DIM, parity, and milk production were provided by CanWest DHI (Guelph, ON, Canada).

\section{Environmental Measures}

Environmental measures in the freestall area have been described by Solano et al. (2015), and included measurements of pens, feed alleys, feeding area, watering area, stall dimensions, number of usable stalls, number of cows within the pen, cleanliness of the pens, and slipperiness of the pen floor. Additionally, the stall was assessed for type of base, type of bedding, depth of bedding, and cleanliness (Solano et al., 2015).

\section{Management}

A questionnaire was administered during farm visits. This questionnaire captured cow comfort related to management practices on the farm (Solano et al., 2015). In short, the management questionnaire captured information on how stalls were maintained (e.g., freestall bedding frequency, freestall cleaning frequency, freestall floor cleaning frequency). The questionnaire is available on the Canadian Dairy Research Portal (https://www. dairyresearch.ca/animal-comfort-tool.php). Additionally, in 2015, questions were added to capture changes that had been made on the farms, including whether farmers had made changes after the assessment in 2011, and what kind of changes they made. The questions asked in the initial phone interview about changes aided in placing farms in their respective study groups.

\section{Statistical Analyses}

Data were entered into Microsoft Access (Microsoft Corp., Redmond, WA), and statistical analyses were performed using Stata 13.1 (2013; StataCorp, College Station, TX). For all analyses, a $P$-value $<0.05$ was considered significant. Descriptive statistics (mean, median, interquartile range) were used to describe both herd- and cow-level characteristics. Variables were tested for collinearity, and continuous variables were tested for normal distribution. If distributions were abnormal, data were $\log$-transformed. If the log-transformation did not meet the preferred distribution, variables were categorized.

Cow-level descriptive statistics for hock and knee injuries were completed by dichotomizing the variable to not injured (scores 0 and 1) and injured (scores 2 and 3). In agreement with the study by Solano et al. (2015), analyses of injury scores were completed using the higher score of the 2 limbs. Claw data were also dichotomous, analyzing the higher of the 2 scores. Two farms in the CHG group, 1 farm in the NC group, and 2 farms in the NF group had $>1$ pens with different environmental characteristics. On these farms, the pen with the largest number of cows in the study was used for analysis. Multiple different characteristics within each pen were classified as "other." Additionally, if environmental variables were uncommon, such as recycled rubber for stall base type (which existed on only 1 farm), they were also classified as "other." If predictor variables were correlated at $r \geq 0.70$ (i.e., stall base and bedding type), only the variable with the strongest association or the higher number of observations was included in the analysis (Solano et al., 2015). These descriptive data were analyzed using Student's $t$ tests for continuous variables and Pearson's chi-squared analysis for categorical variables.

A total of 4 final models were constructed for each of the outcome measures selected for cow comfort and welfare: lameness, lying time, hock injuries, and knee injuries. Logistic regression models were used for lameness and hock and knee injuries; a linear regression model was constructed for lying time. To construct

Table 1. Inclusion criteria for the 3 groups of farms

\begin{tabular}{|c|c|}
\hline Study group & Inclusion criteria \\
\hline $\begin{array}{l}\text { Freestall change } \\
\text { farms (CHG) }\end{array}$ & $\begin{array}{l}\text { Same criteria as for NF herds, plus changes made to one or more of the following after } 2011 \text { assessment }^{1} \text { : stall } \\
\text { dimensions, stall base type, stall bedding type, quantity of stall bedding, number of stalls, barn flooring type }\end{array}$ \\
\hline $\begin{array}{l}\text { No freestall change } \\
\text { farms (NC) }\end{array}$ & $\begin{array}{l}\text { Same criteria as for NF herds, plus no changes made to the following after } 2011 \text { assessment }{ }^{1} \text { : stall dimensions, stall } \\
\text { base type, stall bedding type, quantity of stall bedding, number of stalls, barn flooring type }\end{array}$ \\
\hline
\end{tabular}

${ }^{1}$ Solano et al. (2015). 
each model, univariable analyses were performed for each of these outcomes to identify which explanatory variables had an association $(P \leq 0.25)$ with the outcome variable. Next, a multilevel regression model was constructed for each category of explanatory variables: cow-level variables, environmental variables, and management variables (GLMM in Stata) resulting in 3 models per outcome variable. Variables from each of the 3 models associated with the outcome at $P<0.10$ were included in the final model. Backward elimination was used to build the final model, keeping any confounding variables (when the removal of a variable changed the coefficient of another variable by $30 \%$ ) and any variables significant at $P \leq 0.05$. Interactions were tested between remaining variables that made biological sense or when they were part of the lameness causal web (Solano et al., 2015). In all models, herd was a random effect and study groups were added as fixed effects.

\section{RESULTS}

Of the farms contacted, the 15 CHG farms (Figure 1) are described in Table 2 . The most frequent changes were changing stall base to geomattress $(\mathrm{n}=7)$, increasing bedding quantity $(\mathrm{n}=7)$, and grooving crossover alleys $(n=6)$. The changes included in the study were reported by farmers, although 2 farms ended up switching groups due to discrepancies in what the farmer originally stated and what was measured by the researchers. The 44 farms included had an average herd size of 158 lactating cows. We observed no difference in herd size, average parity, DIM, or daily milk yield be- tween the CHG, NC, and NF groups (Table 3). Claws were less often overgrown in CHG than in $\mathrm{NC}$ and $\mathrm{NF}$. Cows in CHG herds had cleaner legs than cows in NC and NF herds (Table 3). The CHG herds had fewer cows with a BCS $\leq 2.5$ than $\mathrm{NC}$ and NF herds, and more cows with a BCS of 2.75-3.25 than NF herds. The NF herds had more cows with a BCS of $\leq 3.5$ than NC herds (Table 3).

\section{Environmental and Management Variables}

Study groups did not differ in terms of stall dimensions, stall bedding type, or bedding cleanliness (Table 4). The CHG herds were less likely to have rubber mats and more likely to have geomattresses as a stall base than NC herds, and they also had stalls with bedding $\geq 2 \mathrm{~cm}$ more often than $\mathrm{NC}$ and NF herds. The NF herds had wetter stalls than CHG and NC herds. The CHG farms bedded stalls more frequently and had less slippery flooring than did NC and NF (Table 4).

\section{Outcome Variables}

The CHG herds had a lower prevalence of lameness than NC herds and NF herds (Table 5). The prevalence of knee injuries was lower on CHG herds than on NF herds, and CHG herds had a higher average lying time than NC and NF herds (Table 5).

\section{Multivariable Analyses}

Lameness. The final model for lameness included study group, parity, DIM, BCS, hock injury, claw over-

Table 2. Summary of changes to the freestall area after initial assessment of cow comfort (15 change herds, CHG)

\begin{tabular}{ll}
\hline Farm & Freestall area changes \\
\hline 1 & $\begin{array}{l}\text { Replaced rubber mat stall base with geomattress, changed bedding type from straw to shavings, increased bedding quantity and } \\
\text { frequency, grooved crossover alleys }\end{array}$ \\
2 & $\begin{array}{l}\text { Removed previous stall base, changed bedding type from shavings to composted manure, increased bedding quantity } \\
3\end{array}$ \\
$\begin{array}{l}\text { Replaced rubber mat stall base with geomattress, decreased stall length, increased bedding frequency, grooved freestall area } \\
\text { flooring, grooved crossover alleys }\end{array}$ \\
Replaced concrete stall base with rubber mat, changed bedding type from deep bedded straw to shavings, decreased bedding \\
5 & quantity \\
6 & Replaced concrete stall base with geomattress, increased bedding quantity \\
7 & Increased number of stalls, increased width of stalls, replaced old rubber mat stall base with new rubber mats, increased bedding \\
8 & Changed bedding type from straw to shavings, grooved crossover alleys \\
9 & Increased bedding quantity, increased scraping frequency in the freestall area \\
10 & Decreased number of stalls, increased stall width, decreased stall length, replaced rubber mat stall base with geomattress \\
11 & Replaced waterbed stall base with geomattress, increased bedding quantity \\
12 & Replaced concrete stall base with geomattress, changed bedding type from straw to shavings \\
13 & Increased bedding quantity, grooved crossover alleys \\
14 & Replaced rubber mat stall base with geomattress \\
15 & Increased bedding quantity and frequency, grooved crossover alleys \\
\hline
\end{tabular}


Table 3. Distribution of continuous (mean $\pm \mathrm{SD}$ ) and categorical [no. (\%)] cow-level variables on farms that made changes to the freestall area $(\mathrm{CHG})$, made no changes to the freestall area $(\mathrm{NC})$, and new farms $(\mathrm{NF})$

\begin{tabular}{|c|c|c|c|}
\hline Herd or study group characteristic & CHG $(\mathrm{n}=15)$ & $\mathrm{NC}(\mathrm{n}=15)$ & $\mathrm{NF}(\mathrm{n}=14)$ \\
\hline$\overline{\text { Herd size (no. of lactating cows) }}{ }^{1}$ & $160 \pm 75^{\mathrm{a}}$ & $162 \pm 75^{\mathrm{a}}$ & $151 \pm 61^{\mathrm{a}}$ \\
\hline Herd parity ${ }^{1}$ & $2.5 \pm 1.4^{\mathrm{a}}$ & $2.4 \pm 1.1^{\mathrm{a}}$ & $2.3 \pm 1.1^{\mathrm{a}}$ \\
\hline Herd DIM ${ }^{1}$ & $114 \pm 34^{\mathrm{a}}$ & $110 \pm 38^{\mathrm{a}}$ & $111 \pm 27^{\mathrm{a}}$ \\
\hline Parity $^{1}$ & $2.7 \pm 1.6^{\mathrm{a}}$ & $2.3 \pm 1.4^{\mathrm{a}}$ & $2.2 \pm 1.3^{\mathrm{a}}$ \\
\hline $\mathrm{DIM}^{1,2}$ & $95 \pm 99^{\mathrm{a}}$ & $93 \pm 98^{\mathrm{a}}$ & $94 \pm 95^{\mathrm{a}}$ \\
\hline Daily milk yield $(\mathrm{kg})^{1}$ & $37 \pm 10^{\mathrm{a}}$ & $33 \pm 7^{\mathrm{a}}$ & $34 \pm 7^{\mathrm{a}}$ \\
\hline \multicolumn{4}{|l|}{$\mathrm{DIM}^{1}$} \\
\hline $10-60$ & $221(26)^{\mathrm{a}}$ & $207(25)^{\mathrm{a}}$ & $186(26)^{\mathrm{a}}$ \\
\hline $61-120$ & $268(32)^{\mathrm{a}}$ & $231(28)^{b}$ & $220(30)^{\mathrm{ab}}$ \\
\hline $121-180$ & $142(17)^{\mathrm{a}}$ & $161(20)^{\mathrm{a}}$ & $114(16)^{\mathrm{a}}$ \\
\hline $181-240$ & $127(15)^{\mathrm{a}}$ & $117(14)^{\mathrm{a}}$ & $112(15)^{\mathrm{a}}$ \\
\hline $241-300$ & $81(10)^{\mathrm{a}}$ & $102(12)^{\mathrm{a}}$ & $96(13)^{a}$ \\
\hline \multicolumn{4}{|l|}{ Claw length } \\
\hline Not overgrown & $714(85)^{\mathrm{a}}$ & $640(78)^{\mathrm{b}}$ & $544(75)^{\mathrm{b}}$ \\
\hline Overgrown & $125(15)^{\mathrm{a}}$ & $178(22)^{\mathrm{b}}$ & $184(25)^{\mathrm{b}}$ \\
\hline \multicolumn{4}{|l|}{ Leg cleanliness } \\
\hline Clean & $747(89)^{\mathrm{a}}$ & $677(83)^{\mathrm{b}}$ & $566(78)^{\mathrm{b}}$ \\
\hline Dirty & $92(12)^{\mathrm{a}}$ & $141(17)^{\mathrm{b}}$ & $162(22)^{b}$ \\
\hline \multicolumn{4}{|l|}{$\mathrm{BCS}$} \\
\hline$\leq 2.5$ & $260(31)^{\mathrm{a}}$ & $295(36)^{\mathrm{b}}$ & $270(37)^{\mathrm{b}}$ \\
\hline $2.75-3.25$ & $487(58)^{\mathrm{a}}$ & $442(54)^{\mathrm{ab}}$ & $364(50)^{\mathrm{b}}$ \\
\hline$\geq 3.5$ & $92(11)^{\mathrm{ab}}$ & $81(9)^{a}$ & $94(13)^{\mathrm{b}}$ \\
\hline
\end{tabular}

${ }^{\mathrm{a}, \mathrm{b}}$ Within a row, percentages without a common superscript differed $(P<0.05)$.

${ }^{1}$ Data from 2015. Source: CanWest DHI (Guelph, ON, Canada).

${ }^{2}$ Median and interquartile range.

growth, and bedding quantity (Table 6). None of the tested interactions were significant at $P<0.05$. Cows in $\mathrm{NC}$ and $\mathrm{NF}$ herds had higher odds of being lame than cows in CHG herds. Cows in parity 2, 3, 4, and higher had higher odds of lameness than first-parity heifers. Cows at 60-120 and 121-180 DIM had lower odds of being lame than cows in their first 60 DIM or cows later in lactation (181-300 DIM). Cows with a low BCS, injured hocks, and overgrown claws had higher odds of lameness. (Table 6).

Hock and Knee Injuries. Explanatory variables included in the final hock injury model included study group, DIM, lameness, and stall base (Table 6). The prevalence of hock injury was not different among study groups. Cows at 181-240 DIM and cows at >240 DIM had higher odds of a hock injury than cows at $<181$ DIM. Lame cows had higher odds of a hock injury than non-lame cows. Cows using stalls with a geomattress base had higher odds of a hock injury than cows using stalls with a concrete base.

The final model for knee injury included study group, parity, stall base, bedding quantity, and slipperiness (Table 6). We observed no difference in the prevalence of knee injuries among the study groups. Cows in parity $4+$ had higher odds of a knee injury than cows in parity 1. Additionally, cows housed in stalls with bedding $\leq 2$ $\mathrm{cm}$ had higher odds of knee injury. Finally, cows housed in facilities with slippery floors had higher odds of knee injury (Table 6).
Lying Time. The final model for lying time included study group, parity, DIM, lameness, stall curb height, and stall width (Table 7). Cows in NC and NF herds had a lower average daily lying time than cows on CHG herds. Across all groups, cows in parity 3 and $4+$ had a higher lying time than parity 1 and 2 cows. Cows that were $61-120,121-180,181-240$, or $241-300$ DIM had higher lying times than cows that were 0-60 DIM. The lying time of lame cows was higher than that of non-lame cows. Lying time was higher for every $1 \mathrm{~cm}$ over $22 \mathrm{~cm}$ of increased curb height. Last, wider stalls resulted in more prolonged lying time.

\section{DISCUSSION}

The farms included in this study were either part of a study conducted in 2011 that assessed cow comfort in Alberta $(\mathrm{n}=30)$, or had never been exposed to a cow comfort assessment $(\mathrm{n}=14)$. In all statistical models, we observed no difference between the $\mathrm{NC}$ and $\mathrm{NF}$ herds. Therefore, NC groups were not biased by being exposed to a previous evaluation of cow comfort, and results were comparable to farms newly participating in 2015 .

Cows in CHG herds had a lower prevalence of lameness than cows in NC and NF herds. This was not unexpected, because many of the known risk factors for lameness have been identified as environmental factors in the freestall area (Cook and Nordlund, 2009; Chapi- 
Table 4. Distribution of continuous (mean \pm SD) and categorical [no. (\%)] herd-level environmental and management variables for freestall change farms (CHG), no freestall change farms (NC), and new farms (NF)

\begin{tabular}{|c|c|c|c|}
\hline Variable & CHG $(\mathrm{n}=15)$ & $\mathrm{NC}(\mathrm{n}=15)$ & $\mathrm{NF}(\mathrm{n}=14)$ \\
\hline Average stocking density & $1.02 \pm 0.11^{\mathrm{a}}$ & $1.11 \pm 0.20^{\mathrm{ab}}$ & $1.25 \pm 0.17^{\mathrm{b}}$ \\
\hline Width $(\mathrm{cm})$ & $119 \pm 7^{\mathrm{a}}$ & $116 \pm 7^{\mathrm{a}}$ & $114 \pm 5^{\mathrm{a}}$ \\
\hline Bed length $(\mathrm{cm})$ & $180 \pm 10^{\mathrm{a}}$ & $178 \pm 11^{\mathrm{a}}$ & $178 \pm 16^{\mathrm{a}}$ \\
\hline Brisket board $(\mathrm{cm})$ & $11 \pm 5^{\mathrm{a}}$ & $12 \pm 4^{\mathrm{a}}$ & $12 \pm 7^{\mathrm{a}}$ \\
\hline Neck rail height $(\mathrm{cm})$ & $117 \pm 9^{\mathrm{a}}$ & $117 \pm 8^{\mathrm{a}}$ & $115 \pm 7^{\mathrm{a}}$ \\
\hline Neck rail to rear curb $(\mathrm{cm})$ & $172 \pm 8^{\mathrm{a}}$ & $170 \pm 9^{\mathrm{a}}$ & $167 \pm 10^{\mathrm{a}}$ \\
\hline Curb height $(\mathrm{cm})$ & $20 \pm 6^{\mathrm{a}}$ & $22 \pm 4^{\mathrm{a}}$ & $22 \pm 6^{\mathrm{a}}$ \\
\hline \multicolumn{4}{|l|}{ Obstruction in lunge space } \\
\hline Yes & $9(60)^{\mathrm{a}}$ & $11(73)^{\mathrm{a}}$ & $10(71)^{\mathrm{a}}$ \\
\hline No & $6(40)^{\mathrm{a}}$ & $4(27)^{\mathrm{a}}$ & $4(29)^{\mathrm{a}}$ \\
\hline \multicolumn{4}{|l|}{ Stall base type } \\
\hline Concrete & $1(7)^{\mathrm{a}}$ & $4(27)^{\mathrm{a}}$ & $4(29)^{\mathrm{a}}$ \\
\hline Rubber mat & $1(7)^{\mathrm{a}}$ & $2(13)^{\mathrm{ab}}$ & $5(36)^{c}$ \\
\hline Geomattress & $9(60)^{\mathrm{a}}$ & $6(40)^{\mathrm{ab}}$ & $3(21)^{c}$ \\
\hline Waterbed & $1(7)^{a}$ & $1(7)^{a}$ & $0(0)^{\mathrm{a}}$ \\
\hline Other & $3(20)^{a}$ & $2(13)^{\mathrm{a}}$ & $2(14)^{\mathrm{a}}$ \\
\hline \multicolumn{4}{|l|}{ Stall bedding type } \\
\hline Straw & $2(13)^{\mathrm{a}}$ & $2(13)^{\mathrm{a}}$ & $3(21)^{\mathrm{b}}$ \\
\hline Sawdust & $1(7)^{a}$ & $2(13)^{\mathrm{a}}$ & $3(21)^{a}$ \\
\hline Wood shavings & $9(60)^{\mathrm{a}}$ & $7(47)^{\mathrm{a}}$ & $5(36)^{\mathrm{a}}$ \\
\hline Sand & $1(7)^{a}$ & $0(0)^{a}$ & $0(0)^{a}$ \\
\hline Other & $2(13)^{\mathrm{a}}$ & $4(27)^{\mathrm{a}}$ & $3(21)^{\mathrm{a}}$ \\
\hline \multicolumn{4}{|l|}{ Bedding depth $(\mathrm{cm})$} \\
\hline$>2$ & $10(67)^{\mathrm{a}}$ & $6(41)^{\mathrm{b}}$ & $6(43)^{\mathrm{b}}$ \\
\hline$\leq 2$ & $5(33)^{\mathrm{a}}$ & $9(60)^{\mathrm{b}}$ & $8(57)^{\mathrm{b}}$ \\
\hline \multicolumn{4}{|l|}{ Bedding cleanliness } \\
\hline Clean & $14(93)^{\mathrm{a}}$ & $12(80)^{\mathrm{a}}$ & $11(79)^{\mathrm{a}}$ \\
\hline Dirty & $1(7)^{a}$ & $3(20)^{a}$ & $3(21)^{a}$ \\
\hline \multicolumn{4}{|l|}{ Bedding dryness } \\
\hline Dry & $12(80)^{\mathrm{a}}$ & $13(87)^{\mathrm{a}}$ & $10(71)^{\mathrm{b}}$ \\
\hline Wet & $3(20)^{\mathrm{a}}$ & $2(13)^{\mathrm{a}}$ & $4(29)^{\mathrm{b}}$ \\
\hline \multicolumn{4}{|l|}{ Bedding frequency } \\
\hline$>$ Once/wk & $11(73)^{\mathrm{a}}$ & $8(53)^{\mathrm{b}}$ & $6(43)^{\mathrm{b}}$ \\
\hline$\leq$ Once/wk & $4(27)^{\mathrm{a}}$ & $7(47)^{\mathrm{b}}$ & $8(57)^{\mathrm{b}}$ \\
\hline \multicolumn{4}{|l|}{ Slipperiness } \\
\hline Less slippery ( $\leq 3 \%$ slip$)$ & $14(90)^{\mathrm{a}}$ & $12(80)^{\mathrm{b}}$ & $10(71)^{\mathrm{c}}$ \\
\hline More slippery ( $>3 \%$ slip $)$ & $1(10)^{\mathrm{a}}$ & $3(20)^{b}$ & $4(29)^{\mathrm{b}}$ \\
\hline
\end{tabular}

${ }^{\mathrm{a}-\mathrm{c}}$ Within a row, percentages without a common superscript differed $(P<0.05)$.

${ }^{1}$ Previous farms not included in the total, because they were not included in the final models.

nal and de Passillé, 2009; Solano et al., 2015). Additionally, the present study was not the first to demonstrate that monitoring and assessments can decrease lameness prevalence on farms (Chapinal et al., 2014b). In the present study, risk factors for lameness were similar to those reported by Solano et al. (2015), although the

Table 5. Cow-level prevalence [no. (\%)] of lameness, hock, and knee injuries and average lying time for freestall change farms $(\mathrm{CHG})$, no freestall change farms (NC), and new farms (NF)

\begin{tabular}{lccc}
\hline Variable & CHG $(\mathrm{n}=15)$ & NC $(\mathrm{n}=15)$ & NF $(\mathrm{n}=14)$ \\
\hline Lameness & $747(89)^{\mathrm{a}}$ & $660(81)^{\mathrm{b}}$ & $560(78)^{\mathrm{b}}$ \\
$\quad$ Not lame & $92(11)^{\mathrm{a}}$ & $158(19)^{\mathrm{b}}$ & $160(22)^{\mathrm{b}}$ \\
Lame & $788(94)^{\mathrm{a}}$ & $775(95)^{\mathrm{a}}$ & $677(93)^{\mathrm{a}}$ \\
Hock injuries & $51(6)^{\mathrm{a}}$ & $43(5)^{\mathrm{a}}$ & $51(7)^{\mathrm{a}}$ \\
$\quad$ Not injured (score 0-1) & $814(97)^{\mathrm{a}}$ & $769(94)^{\mathrm{ab}}$ & $662(91)^{\mathrm{b}}$ \\
Injured (score 2-3) & $25(3)^{\mathrm{a}}$ & $49(6)^{\mathrm{ab}}$ & $66(9)^{\mathrm{b}}$ \\
Knee injuries & $12.6 \pm 2.3^{\mathrm{a}}$ & $10.7 \pm 2.2^{\mathrm{b}}$ & $10.2 \pm 3.1^{\mathrm{b}}$ \\
$\quad$ Not injured (score 0-1) & & \\
Injured (score 2-3) & & \\
Average hours lying per day (mean \pm & &
\end{tabular}

${ }^{\mathrm{a}, \mathrm{b}}$ Within a row, percentages or estimates without a common superscript differed $(P<0.05)$. 
Table 6. Final logistic regression models for lameness and hock and knee injuries, including cow and herd-level variables from 44 dairy farms in Alberta, Canada

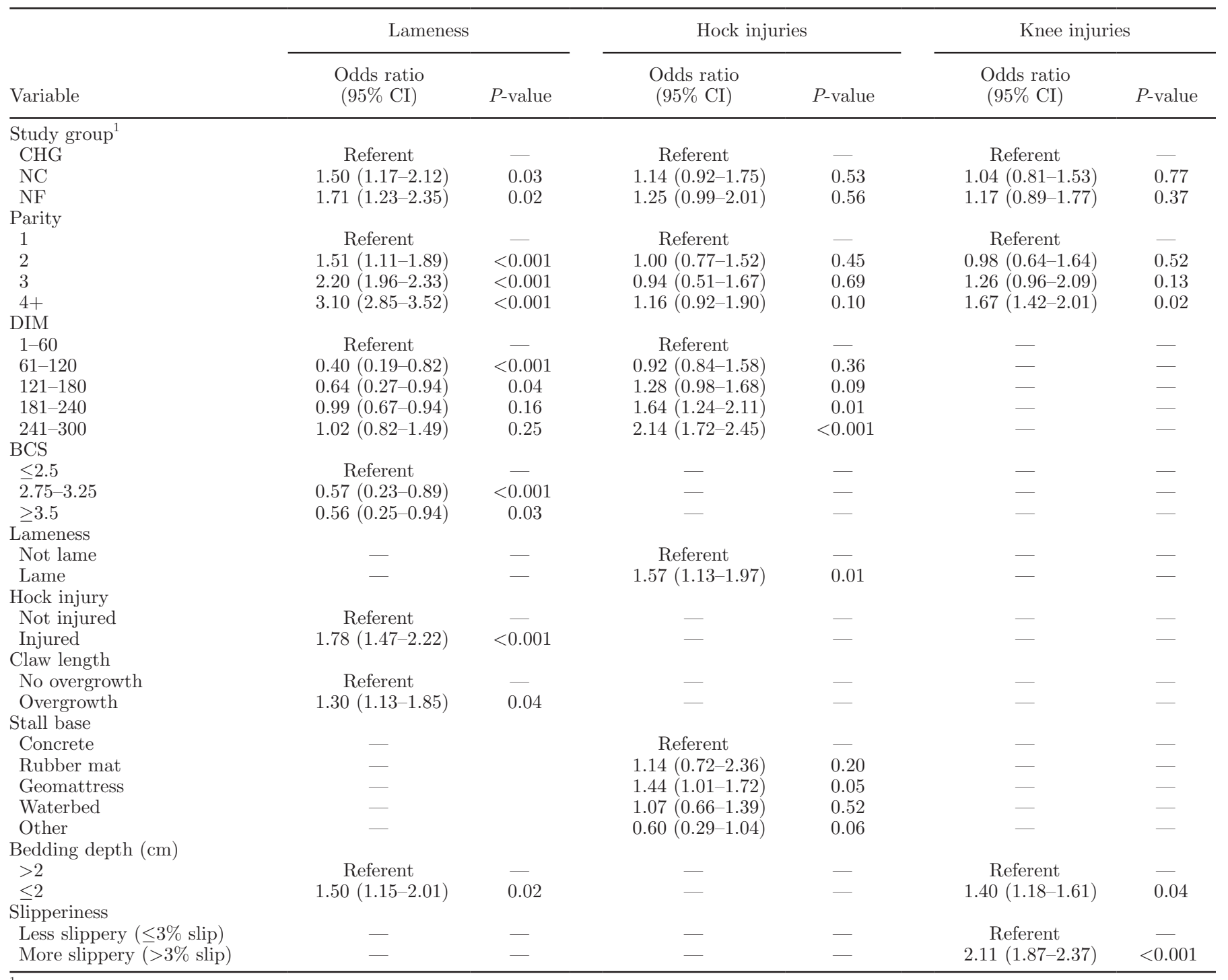

${ }^{1} \mathrm{CHG}=$ farms that made changes to the freestall area after a previous cow comfort assessment; NC $=$ farms that did not make changes to the freestall area after a previous cow comfort assessment; $\mathrm{NF}=$ farms that had not been exposed to the previous cow comfort assessment.

results for certain risk factors differed from this study and other literature (Whay et al., 2012; Chapinal et al., 2014a). For example, stall base was not associated with lameness prevalence. Due to a limited number of farms with specific stall bases, many stall base options were classified as "other," possibly masking the effect of certain bases on lameness. In Canada, studies using the same standard operating procedures reported similar results in early lactation (Zaffino Heyerhoff et al., 2014; Solano et al., 2015), although they were not able to capture the decreased prevalence of lameness mid-lactation and increased prevalence of lameness in the last 181-300 DIM. Although this was a novel result for Canadian studies, this trend has been reported elsewhere (Warnick et al., 2001).

Cows in CHG herds had longer lying times than cows in NC and NF herds. This was consistent with our hypothesis, because factors affecting lying time (similar to lameness) include both cow factors and freestall environmental factors (Solano et al., 2015). An important factor to highlight from the lying time model was the broad range of DIM. In the present study, lying time increased with increasing DIM. This is particularly interesting when considering that lameness prevalence was higher in the last 181-300 DIM, because we know that lameness and lying time have a complicated rela- 
tionship. In that regard, although prolonged lying time can demonstrate good cow comfort, it is also highly prevalent among severely lame animals (Solano et al., 2016). However, we observed an increase in lameness prevalence at the end of lactation, and the increased prevalence of lameness may have caused the increased lying time at this stage. However, our study was crosssectional, and this finding should be substantiated with longitudinal studies.

The prevalence of both hock and knee injuries was not different on CHG herds compared to NC and NF herds. This finding was in contrast to a study by Chapinal et al. (2014b), which found a decrease in hock injuries after participation in an assessment program. We inferred that changes made to the freestall area might be less successful at improving leg injuries, even though the causal diagram specifies that stall dimensions, bedding type, base, and management affect these injuries (Zaffino Heyerhoff et al., 2014). However, this study did not address how specific changes affected various outcome measures. Producers made many changes on their farm at different times, making it difficult to determine which changes, or combination of changes, were having the greatest effect. However, the most popular changes that occurred on selected farms in this study included changing the stall base to geomattress, increasing bedding quantity, and grooving crossover alleys. According to the literature, stall base is an important risk factor for leg injuries, because they can be hard and abrasive (Huxley and Whay, 2006; Kielland et al., 2009). However, several farms changed stall base (switched to mattresses). The surface of mattresses are typically abrasive to reduce slip, and, along with rubber mats and concrete, have been known to increase the prevalence of leg injuries (Huxley and Whay, 2006). Although many farmers increased bedding depth, we did not analyze how much deeper the bedding was; we only recorded whether the bedding was above or below $2 \mathrm{~cm}$. As well, we did not see many farmers change to ideal bedding types to prevent hock and knee injuries. Deep bedded straw or, more preferably, sand, decrease leg injuries (Huxley and Whay, 2006). Additionally, stall dimensions have an effect, with longer resting areas being optimal for decreasing leg injuries (Kielland et al., 2009; Zaffino Heyerhoff et al., 2014). This change was not frequently observed in study farms.

A longitudinal study following specific changes would be beneficial for understanding the effects of specific changes on various animal-based measures of cow comfort. Such a study would require more cows to under-

Table 7. Final generalized linear model for lying time including cow- and herd-level factors in 44 Alberta dairy herds with cow within-herd as the experimental unit

\begin{tabular}{|c|c|c|c|}
\hline Variable & Estimate & $95 \%$ CI & $P$-value \\
\hline Intercept & 10.11 & 8.55 to 11.03 & - \\
\hline \multicolumn{4}{|l|}{ Study group ${ }^{1}$} \\
\hline $\mathrm{CHG}$ & Referent & - & - \\
\hline $\mathrm{NC}$ & -0.33 & -0.59 to -0.22 & 0.001 \\
\hline $\mathrm{NF}$ & -0.62 & -0.71 to -0.45 & 0.001 \\
\hline \multicolumn{4}{|l|}{ Parity } \\
\hline 1 & Referent & - & - \\
\hline 2 & 0.12 & -0.18 to 0.37 & 0.35 \\
\hline 3 & 0.55 & 0.36 to 1.11 & $<0.001$ \\
\hline $4+$ & 0.83 & 0.58 to 1.16 & $<0.001$ \\
\hline \multicolumn{4}{|l|}{ DIM } \\
\hline $0-60$ & Referent & - & - \\
\hline $61-120$ & 0.41 & 0.18 to 0.80 & $<0.001$ \\
\hline $121-180$ & 1.11 & 0.81 to 1.34 & $<0.001$ \\
\hline $181-240$ & 1.17 & 0.86 to 1.41 & $<0.001$ \\
\hline $241-300$ & 1.62 & 1.44 to 1.88 & $<0.001$ \\
\hline \multicolumn{4}{|l|}{ Lameness } \\
\hline Not lame & Referent & - & - \\
\hline Lame & 0.44 & 0.29 to 0.56 & $<0.001$ \\
\hline Stall curb height $>22 \mathrm{~cm}$ (per $1-\mathrm{cm}$ increase) & 0.05 & 0.01 to 0.07 & 0.03 \\
\hline \multicolumn{4}{|l|}{ Bedding depth (cm) } \\
\hline$\geq 2$ & Referent & - & - \\
\hline$<2$ & -0.11 & -0.16 to 0.07 & 0.004 \\
\hline \multicolumn{4}{|l|}{ Stall width $(\mathrm{cm})$} \\
\hline$<114$ & Referent & - & - \\
\hline$\geq 114$ & 0.41 & 0.11 to 0.75 & 0.048 \\
\hline
\end{tabular}

${ }^{1} \mathrm{CHG}=$ farms that made changes to the freestall area after a previous cow comfort assessment; NC $=$ farms that did not make changes to the freestall area after a previous cow comfort assessment; NF = farms that had not been exposed to the previous cow comfort assessment. 
stand how each change affected the herd and would allow for a greater variety in parity and DIM. Additionally, it would be beneficial for a future study to consider how cows are housed during their dry period, because a cow may have been injured or lame before joining the milking herd. Factors associated with hoof trimming should also be considered in the future, because this study did not include changes made to hoof trimming protocols. Depending on location, temperature should also be assessed. Temperature was not assessed in this paper, because dairy cows in Alberta are not exposed to heat stress. Heat stress can have a negative effect on cow comfort by causing many physiological problems (Kadzere et al., 2002). Finally, it would be beneficial to use qualitative assessments to help identify unknown barriers and motivators for improvements to risk factors associated with cow comfort. Leach et al. (2010 $a, b)$ identified barriers that prevent farmers from improving lameness, such as lack of labor, and identified motivators, including taking pride in having a healthy herd. However, farmers often underestimate the prevalence of animal-based measures of cow comfort, such as lameness, in their herds (Whay et al., 2002). If farmers participate in cow comfort assessments and are exposed to the results, they may be motivated to improve overall herd health on their farms.

\section{CONCLUSIONS}

Overall, CHG herds had a lower prevalence of lameness and higher average daily lying time compared with NC and NF herds. No variables differed between the NF and $\mathrm{NC}$ herds, demonstrating that they were comparable groups. The CHG herds had better cow comfort than the NC and NF herds.

\section{ACKNOWLEDGMENTS}

The authors thank participating farmers, collaborators, technicians, students, and CanWest DHI for their support with this study. We are especially grateful for the contributions of Casey Jacobs, Colin Nichols (University of Calgary, Calgary, AB, Canada), and Raisa Engelbert (Utrecht University, Utrecht, the Netherlands) in data collection. We thank Steve Mason for establishing the database. We also thank John Kastelic for editing this manuscript. This study was funded by the Dairy Farmers of Canada (Ottawa, ON, Canada).

\section{REFERENCES}

Barkema, H. W., M. A. G. von Keyserlingk, J. P. Kastelic, T. J. G. M. Lam, C. Luby, J.-P. Roy, S. J. LeBlanc, G. P. Keefe, and D. F.
Kelton. 2015. Invited review: Changes in the dairy industry affecting dairy health and welfare. J. Dairy Sci. 98:7426-7445.

Chapinal, N., A. M. de Passillé, D. M. Weary, M. A. G. von Keyserlingk, and J. Rushen. 2009. Using gait score, walking speed, and lying behavior to detect hoof lesions in dairy cows. J. Dairy Sci. 92:4365-4374.

Chapinal, N., Y. Liang, D. M. Weary, Y. Wang, and M. A. G. von Keyserlingk. 2014a. Risk factors for lameness and hock injuries in Holstein herds in China. J. Dairy Sci. 97:4309-4316.

Chapinal, N., D. M. Weary, L. Collings, and M. A. G. von Keyserkingk. 2014b. Lameness and hock injuries improve on farms participating in an assessment program. Vet. J. 202:646-648.

Cook, N. B. 2006. Footbath alternatives. Accessed Jan. 26, 2017. http://www.vetmed.wisc.edu/dms/fapm/fapmtools/61ame/ Footbath_Alternatives.pdf

Cook, N. B., T. B. Bennett, and K. V. Nordlund. 2004. Effect of freestall surface on daily activity patterns in dairy cows with relevance to lameness prevalence. J. Dairy Sci. 87:2912-2922.

Cook, N. B., and K. V. Nordlund. 2009. The influence of the environment on dairy cow behavior, claw health and herd lameness dynamics. Vet. J. 179:360-369.

Gibbons, J., E. Vasseur, J. Rushen, and A. M. de Passillé. 2012. A training programme to ensure high repeatability of injury scoring of dairy cows. Anim. Welf. 21:379-388.

Green, L. E., V. J. Hedges, Y. H. Schukken, R. W. Blowey, and A. J. Packington. 2002. The impact of clinical lameness on the milk yield of dairy cattle. J. Dairy Sci. 85:2250-2256.

Huxley, J. N., and H. R. Whay. 2006. Current attitudes of cattle practitioners to pain and the use of analgesics in cattle. Vet. Rec. 159:662-668

Ito, K. 2009. Assessing cow comfort using lying behaviour and lameness. MSc Thesis. University of British Columbia, Vancouver, Canada.

Kadzere, C. T., M. R. Murphy, N. Silanikove, and E. Maltz. 2002. Heat stress in lactating dairy cows: A review. Livest. Prod. Sci. 77:59-91.

Kielland, C., L. E. Ruud, A. J. Zanella, and O. Osteras. 2009. Prevalence and risk factors for skin lesions on legs of dairy cattle housed in freestalls in Norway. J. Dairy Sci. 92:5487-5496.

Leach, K. A., H. R. Whay, C. M. Maggs, Z. E. Barker, E. Paul, and D. C. J. Main. 2010a. Working towards a reduction in cattle lameness: 1 . Understanding barriers to lameness control on dairy farms. Res. Vet. Sci. 89:311-317.

Leach, K. A., H. R. Whay, C. M. Maggs, Z. E. Barker, E. Paul, and D. C. J. Main. 2010b. Working towards a reduction in cattle lameness: 2. Understanding dairy farmers' motivations. Res. Vet. Sci. $89: 318-323$.

National Farm Animal Care Council. 2009. Code of practice for the care and handling of dairy cattle. Accessed Feb. 28, 2017. http:// www.nfacc.ca/codes-of-practice/dairy-cattle.

Nechanitzky, K., A. Starke, B. Vidondo, H. Müller, M. Reckardt, K. Friedli, and A. Steiner. 2016. Analysis of behavioral changes in dairy cows associated with claw horn lesions. J. Dairy Sci. 99:2904-2914.

Rushen, J., D. Haley, and A. M. de Passille. 2007. Effect of softer flooring in tie stalls on resting behavior and leg injuries of lactating cows. J. Dairy Sci. 90:3647-3651.

Solano, L., H. W. Barkema, E. A. Pajor, S. Mason, S. J. LeBlanc, C. G. R. Nash, and K. Orsel. 2016. Associations between lying behavior and lameness in Canadian Holstein-Friesian cows housed in freestall barns. J. Dairy Sci. 99:2086-2101.

Solano, L., H. W. Barkema, E. A. Pajor, S. Mason, S. J. LeBlanc, J. C. Zaffino Heyerhoff, and K. Orsel. 2015. Prevalence of lameness and associated risk factors in Canadian Holstein-Friesian cows housed in freestall barns. J. Dairy Sci. 98:6978-6991.

Vasseur, E., J. Gibbons, J. Rushen, and A. M. de Passillé. 2013. Development and implementation of a training program to ensure high repeatability of body condition scoring of dairy cows. J. Dairy Sci. 96:4725-4737. 
Vasseur, E., J. Gibbons, J. Rushen, D. Pellerin, E. Pajor, D. Lefebvre and A. M. de Passillé. 2015. An assessment tool to help producers improve cow comfort on their farms. J. Dairy Sci. 98:698-708.

von Keyserlingk, M. A. G., A. Barrientos, K. Ito, E. Galo, and D. M. Weary. 2012. Benchmarking cow comfort on North American freestall dairies: Lameness, leg injuries, lying time, facility design, and management for high-producing Holstein dairy cows. J. Dairy Sci. 95:7399-7408.

Wang, F. X., D. F. Shao, S. L. Li, Y. J. Wang, A. Azarfar, and Z. J Cao. 2016. Effects of stocking density on behavior, productivity, and comfort indices of lactating dairy cows. J. Dairy Sci. 99:3709 3717 .

Warnick, L. D., D. Janssen, C. L. Guard, and Y. T. Gröhn. 2001. The effect of lameness on milk production in dairy cows. J. Dairy Sci. 84:1988-1997.

Weary, D. M., J. M. Huzzey, and M. A. G. von Keyserlingk. 2009. Using behavior to predict and identify ill health in animals. J. Anim. Sci. 87:770-777.
Whay, H. R., Z. E. Barker, K. A. Leach, and D. C. Main. 2012. Promoting farmer engagement and activity in the control of dairy cattle lameness. Vet. J. 193:617-621.

Whay, H. R., D. C. J. Main, L. E. Green, and A. J. F. Webster. 2002. Farmer perceptions of lameness prevalence. Pages 355-358 in Proc. 12th Int. Symp. Lameness in Ruminants, Orlando, FL. J. K. Shearer, ed. 12th Int. Symp. Lameness in Ruminants, Organizing Committee, Orlando, FL.

Zaffino Heyerhoff, J. C., S. J. LeBlanc, T. J. DeVries, C. G. R. Nash, J. Gibbons, K. Orsel, H. W. Barkema, L. Solano, J. Rushen, A. M. de Passillé, and D. B. Haley. 2014. Prevalence of and factors associated with hock, knee, and neck injuries on dairy cows in freestall housing in Canada. J. Dairy Sci. 97:173-184. 